S. Čiháková Aguilar, et al., Int. J. Sus. Dev. Plann. Vol. 7, No. 2 (2012) 209-220

\title{
ADVANCED TECHNOLOGY VALUATION OF THE INDUSTRIAL UTILIZATION OF NANOTECHNOLOGY
}

\author{
S. ČIHÁKOVÁ AGUILAR, M. DUBOVÁ \& E. MUCSKOVÁ \\ Institute of Novel Technologies and Applied Informatics, Technical University of Liberec, Czech Republic.
}

\begin{abstract}
This article focuses on valuation of biological wastewater treatment (WWT) technology with the application of nano-fibrous carrier. The economic analysis and assessment of this developing technology is based on the data from the technology using Anoxkaldnes ${ }^{\mathrm{TM}}$ carriers. The first part describes the methods of valuation of technology. The following analyses are presented: cost analysis, depreciation model, model of production chemical agent DPG and cash flow model. There are sensitivity analyses exploring the impact on the price of chemical agent DPG, increase of its production, price of applied carriers and accident frequency, and pro forma income statement. Results show that the application of WWT technology with the nano-fibrous carrier is a right choice in compliance with long-term economic and ecological indicators in relation to the sustainable growth of the company.

Keywords: biological waste water treatment technology, cash flow model, cost analysis, depreciation model, nano fiber, valuation of technology.
\end{abstract}

\section{INTRODUCTION}

Nowadays, the evolution of the nanotechnology is having a great impact on most of the industrial branches. This article focuses on the application of nanotechnology in the branch of industrial wastewater treatment. This paper describes the application of nano-fibrous carrier of biomass in biological wastewater treatment facilities. This technology is being tested in a research phase at one of the projects of the Advanced Remediation Technologies and Processes Center of the Technical University in Liberec (Czech Republic).

The research is being developed on the basis of diverse disciplines such as chemistry, engineering of natural resources, development of textile materials, and mathematic modeling, among others.

The economic valuation of the mentioned technology is based on the comparison with the already applied technology for wastewater treatment using carriers "Anoxkaldnes ${ }^{\text {TM". }}$. Because of the existence of sensitive data, we decided to keep the company in anonymity and call it "Company A" for the purposes of this work.

The aim of this article is to describe the issues and methods concerning valuation of progressive technologies focused on the industrial application of nanotechnology. We also intend to define advantages and disadvantages of the application of the valuation methods in order to make a suggestion for further work on research and practical application of nanotechnology at the industrial branch.

The whole work was developed under the aid of MS Excel in order to allow actualizations and interconnections among different parts of the model. This might lead to better orientation through the results and will, therefore, ease the decision making process. We selected the methods according to the criteria shown on Table 1.

\section{VALUATION OF NEW TECHNOLOGIES}

The process of valuation has been for a long time a subject of interest. The subject of valuation can be material things, such as houses and jewels, but also more abstract ones, such as new technologies. The term valuation refers to the monetary roles of particular goods [1]. There are three methodologies

(C) 2012 WIT Press, www.witpress.com

ISSN: 1743-7601 (paper format), ISSN: 1743-761X (online), http://journals.witpress.com

DOI: $10.2495 /$ SDP-V7-N2-209-220 
Table 1: Selected valuation methods.

\begin{tabular}{ll}
\hline \multicolumn{1}{c}{ Methods } & \multicolumn{1}{c}{ Advantages of the method } \\
\hline Cost analysis & $\begin{array}{l}\text { Useful for comparison between (new) } \\
\text { technologies } \\
\text { Show a wide range of factors that influence the } \\
\text { cash flows corresponding to a specific technology. } \\
\text { Cash flow, }\end{array}$ \\
Internal rate of return & $\begin{array}{l}\text { IRR and NPV present a dynamic method for the } \\
\text { valuation of technologies } \\
\text { Changes are inherent in technology development. } \\
\text { Sensitivity analysis }\end{array}$ \\
& $\begin{array}{l}\text { Sensitivity analysis valuate changes in } \\
\text { effectiveness due to changes in the original } \\
\text { characteristics of the investments } \\
\text { Give useful information about the management } \\
\text { performance towards decisions concerning } \\
\text { investments in technology }\end{array}$ \\
Pro forma financial & \\
statements &
\end{tabular}

Source: own.

traditionally used for the determination of the value of property: market approach, income approach and cost approach [2]. All of these traditional ways of valuation can help to establish the economic and physical characteristics of certain property. Each of these methodologies can present some variations due to the diversity of valuators, which might adapt the results according to the final application of the valuation.

Two different groups work during the process of transformation of research into a new technology: scientists and financial managers. The existence of different backgrounds is one of the main reasons for the difficulty in communication among these groups.

The valuation of technologies can serve as a bridge that can bring together the ideas towards an appropriate decision making process related to new technology [1, 3].

The valuation of technologies is a complex task and can be applied just within the context of a specific business situation or specific company. Some of the methods are listed below:

- Cost analysis

- Pro forma analysis NPV \& IRR

- Net present value and analysis of internal rate of return

- Sensitivity analysis

- Decision trees

- Risk analysis

- Monte Carlo methods

- Portfolio analysis

- Shortcut methods [1]

Figure 1 provides a road map to the approach to the valuation of technology. Input data are shown as ovals, whereas methods are shown as rectangles. 


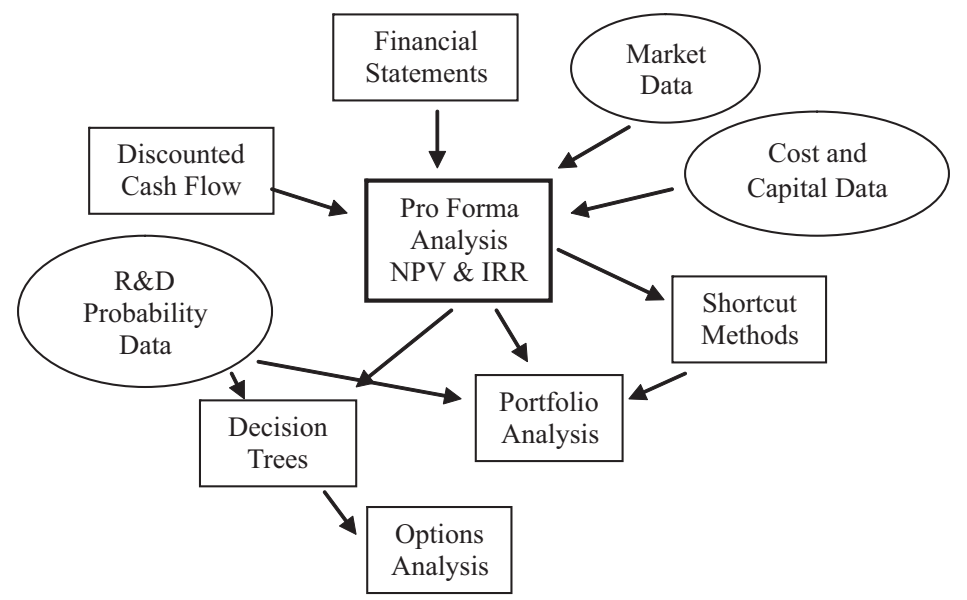

Figure 1: Technology valuation roadmap [1].

\section{VALUATION OF TECHNOLOGIES FOR WASTEWATER TREATMENT}

A new technology using nanofiber for wastewater treatment has been developed and tested within the research and development project "Advanced Remediation Technologies and Processes Center". The research is in charge of several scientific teams of different branches (chemistry, natural sciences, engineering, mathematic modeling). At the present time, an economic valuation of the technology is also taking place in the project, which is based on the comparison of the current applied technology using Anoxkaldnes ${ }^{\mathrm{TM}}$ biofilm by a company, the name of which is not mentioned in this work due to the existence of sensitive data. (For the purposes of this article, we called it "Company A".) Section 3.2 describes the technology used by Company A and Section 3.3 describes the nanotechnology.

Modern methods of valuation and corporate financial management can be applied for the valuation of technologies for wastewater treatment. The information provided by the experts on technology is translated by the economic team into valuation models containing detailed cost analyses that describe the wastewater treatment technology.

\subsection{Chemical/biological wastewater treatment plant}

The reconstructed industrial chemical/biological wastewater treatment plant of Company A is determined at the present time for:

- Decontamination of wastewater containing cyanide and organic materials for residual waters originated in technological processes for the production of diphenylguanidine (DPG) and acetone cyanohydrin $(\mathrm{ACH})$

- Reduction of the contents of cyanide in wastewater from the production of diphenylguanidine [4].

Implementation of biological treatment of wastewater was the reason for the innovation of production of the plant, which might lead to an increase on production. Consequently, the plant management decided to combine the innovation of production with the construction of the new water treatment plant. The whole investment deals with modernization of chlorocyan 
and diphenylguanidine (DPG) production with the aim of increasing process safety, production capacity, and continuity of chlorocyan production. The environmental safety of production is secured by non-waste combined physicochemical and biological treatment of wastewater in the newly established wastewater treatment plant. Diphenylguanidine is a highly sophisticated component used in the rubber industry (tire production) costing approx. 2500 EUR per ton. The reconstruction of the production unit enables the plant to increase production twofold (from $900 \mathrm{t} / \mathrm{year}$ to almost $2000 \mathrm{t} /$ year) together with the implementation of a safety system for wastewater treatment.

Implementation of new water treatment technology enables the plant to fulfill the requirements of the Integrated Pollution Prevention and Control (IPPC) Act, as well as the requirements of the new Water and Waste Acts. The company produces about $20 \%$ of the worldwide production of DPG. The DPG market is stable and has an annual increase of approx. 5\%. The prognoses revealed the same increase in demand of DPG in the coming years. Investment into modernizing the production and improvement of the wastewater treatment create the possibility for sustainable development of the company, maintain existing jobs, and bring the possibility for new jobs in the coming years [5].

\subsection{Technology using Anoxkaldnes ${ }^{\mathrm{TM}}$ biofilm}

With the technology, Anoxkaldnes ${ }^{\mathrm{TM}}$ can use plastic carriers to take up to $70 \%$ of the volume of the water deposit; the carriers are designed to be suspended on water and therefore to enable a more protected surface for the growth of biofilm and optimal conditions for the development of bacteria. This technology can be applied for industrial and for municipal wastewater treatment. One of the greatest advantages is the high flexibility of the process, which enables to combine the system in different forms with the classical activation process depending on how appropriate it might be for the effective dissolution of contaminants. This technology reports a stable high efficiency of elimination of pollutants from $80 \%$ to $99 \%$. Another interesting fact is its low production of sediments, which also helps to decrease costs.

The technology is of growing biofilm in the internal surface of the carriers' structure. These are plastic 'wheels' with different structures, depending on the type. The form is determinant for the demands on transport of substrates and oxygen to the microorganisms.

The diameter of the carrier K3 is $25 \mathrm{~mm}$, the total usable surface is $600 \mathrm{~m}^{2} / \mathrm{m}^{3}$, from which the internal protected surface is $500 \mathrm{~m}^{2} / \mathrm{m}^{3}$. The density $1000 \mathrm{~kg} / \mathrm{m}^{3}$ of the applied carrier material ensures that the density of the biocomplex gets about the level of wastewater for the growth of biomass on the carrier. For the maintenance of their suspension is important to release minimum energy [7].

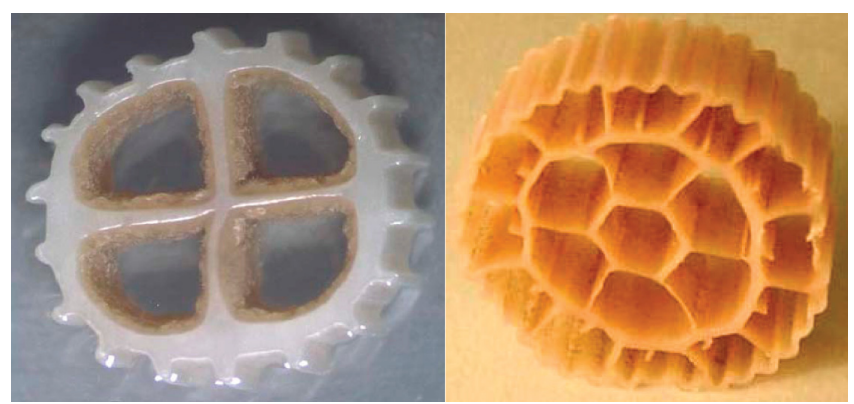

Figure 2: Technology Anoxkaldnes ${ }^{\mathrm{TM}}$, K1 industrial, K3 municipal [6]. 


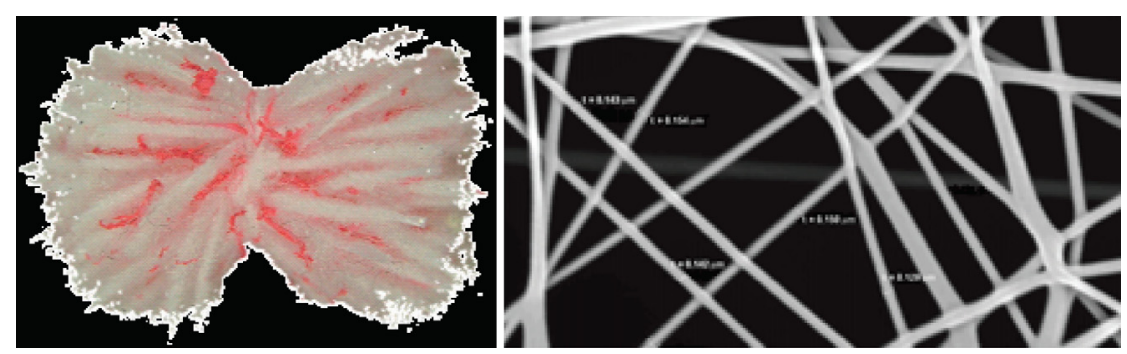

Figure 3: Nano-fibrous carrier, detail of the nano-fibrous layer (SEM) [7, 8].

\subsection{Polypropylene, polyurethane and nano-fibrous carriers}

This technology was created by the Department of Nonwoven Textiles of the Technical University in Liberec and developed by the Center for Advanced Technologies and Processes for wastewater treatment. It represents a more flexible polymeric carrier than the one used by Anoxkaldnes ${ }^{\mathrm{TM}}$ and have the following advantages:

- An effective surface, which is supported by a nano-fibrous film with a highly specific protected surface. This allows bacteria high adhesivity (enables their immobilization) mainly at the first stages of the carrier's surface colonization.

- A big advantage of this technology is the possibility of combination of different polymers in order to set the carriers density (from $900 \mathrm{~kg} / \mathrm{m}^{3}$ for PP until $1200 \mathrm{~kg} / \mathrm{m}^{3}$ for PU).

- Other advantages of the nano-fibrous carriers are durability, easy formation, resistance against chemicals, low thermal characteristics and resistance against abrasion (mainly with nanofilm).

- A greater selection of the structure and design of the carriers, which minimizes for example the cost of mixtures.

- A significant advantage of this technology is the application of biofilm growing in the internal surface of the carriers' structure. With this design, bacteria are better protected from the toxic influence of the surrounding environment and are determinant for the demands on transport of substrates and oxygen to the microorganisms [7].

From the economic point of view, these carriers have the following advantages:

Higher efficiency for the elimination of contamination (results from laboratory tests).

The cleaning process becomes renewable in a faster way in case of a plant failure. This leads also to the following effects:

a) Shorter shut-down. Serious failures on wastewater treatment plants, which can appear 1-2 times a year, represent a reduction in the production of about $8-16 \%$ (1-2 months). The process can be restarted up to 2 times faster with the application of nano-fibrous carriers compared with the technology using Anoxkaldnes ${ }^{\mathrm{TM}}$ (4-8\% reduction of production a year).

b) Higher stability of the cleaning process and, therefore, lower ecological related fines.

\section{STRUCTURE OF THE ECONOMIC MODEL FOR WASTEWATER TREATMENT TECHNOLOGY FOR THE CZECH REPUBLIC}

The suggested model for the valuation of wastewater treatment technology is a result of the review of theoretical and technological issues, the information from the scientific groups and the principles 
of corporate financial management as described in [1-3, 9]. The MS Excel processor might be used for its elaboration. Thanks to the application of the software support, it is possible to simulate trends of values in case of changes in relevant variables. The model of valuation of the technology of wastewater treatment can be useful for more efficient decision making processes.

The authors suggested the following structure of the general economic model for the valuation of wastewater treatment technologies:

- Cost model for wastewater treatment technology

- Depreciation model for wastewater treatment

- Cash flow model for wastewater treatment (NPV, IRR)

- Production model

- Sensitivity analysis (for product's final price, material's final price, failures and breakdowns)

4.1 Cost model for the wastewater treatment technology

The cost model (or also cost analysis) can be useful for the detailed analysis of technologies for wastewater treatment. It can be used for the calculation of total costs before the first operations of the plant and also for the costs during the whole life of operation of the plant. This model has been prepared in MS Excel format, which enables the automatic calculation of data.

The cost analysis was created for two types of technologies for wastewater treatment: for the technology using Anoxkaldnes ${ }^{\mathrm{TM}}$ carriers which is an international trademark and for the technology using nano-fibrous carriers that corresponds to the results of a research phase pursued at the laboratories of the Technical University in Liberec.

There are three important categories of costs for the wastewater treatment technology:

A) Startup costs and expenditures of the wastewater treatment plant,

B) Operation costs during 1 year,

C) Modernization of the production process of DPG (incremental costs).

Startup costs and investments for the reconstruction of the wastewater treatment plant and the optimization of the production at the Company A using the Anoxkaldnes ${ }^{\mathrm{TM}}$ carriers reach a total value of 61979 000,- CZK. (At the time of ending this work, the exchange rate was 24,73 CZK/1 EUR). Investment costs that correspond to the reconstruction of the plant amount to 2248000 ,- CZK, the costs for the optimization of the production amount 35500 000,- CZK. These expeditures caused and increment of the production of DPG at about 1100 tons.

Non-capital costs (expenditures) amount 3999 000,- CZK. The investment for the refill might amount to $2505000,-\mathrm{CZK}$ in case of the utilization of the nano-fibrous carrier and if all the other parameters for the actual technology remain untouched.

Additional capital costs for the wastewater treatment technology amount the following values (for both types of carrier):

Construction 22098 00,- CZK; Pre-project working 1550 000,- CZK; Research costs including scientific testing 660 000,- CZK; and Operation costs for one year of the plant operations 1267 000,- CZK.

\subsection{Depreciation model}

There are two types of depreciation: book and tax depreciations. Book depreciation is calculated in different forms by each company. For purposes of this work, we decided to apply tax depreciation due to its general validity for companies in the Czech Republic [10]. 
Our model calculates automatically the depreciation and residual prices for each year of the plant's lifetime and it's based on the Czech income tax law.

All the components of the wastewater treatment plant are subject of tax depreciation in the Czech Republic. $10 \%$ of the technology is subject of tax depreciation belonging to the 4th group (20 year depreciation life). The rest belongs to the 30 years depreciation life (5th group).

It was also necessary to estimate the depreciation for the investments for production optimization (35 500 000,- CZK), which belongs to the 4th group.

\subsection{Cash flow model}

First step: user enters variable criteria (yellow cells), Second step: model automatically calculates on the basement of entered data in previous worksheets:

- Total earnings $=$ Earnings after taxes + depreciation tax shield,

- Capital outlays into the WWT,

- Net present value at the end of useful life of the technology,

- Net present value in the year of max. payback period,

- Payback period,

- Internal rate of return,

- Average costs,

- Financing only by equity, financing by equity + bank credit

The Net Present Value for the investment on the technology Anoxkaldnes ${ }^{\mathrm{TM}}$ taking into account the optimization of the production amounts 541372 841,- CZK financed by own capital. The Net Present Value after 15 years financed the same way amounts 458009 217,- CZK.

Figure 4 shows the relation between accumulated discounted revenue and accumulated discounted capital expenses including the net present value financed by own capital.

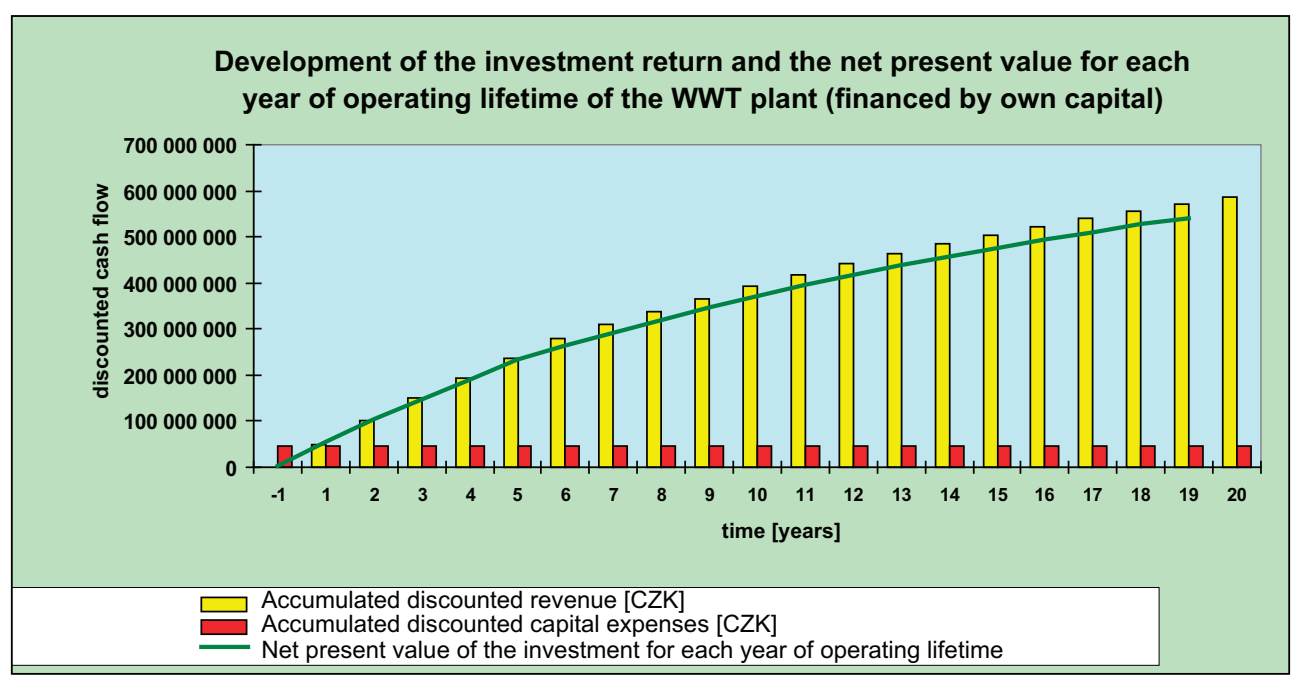

Figure 4: Development of the investment return and the net present value for each year of operating lifetime of the WWT plant using Anoxkaldnes ${ }^{\mathrm{TM}}$ (financed by own capital). Source: own. 


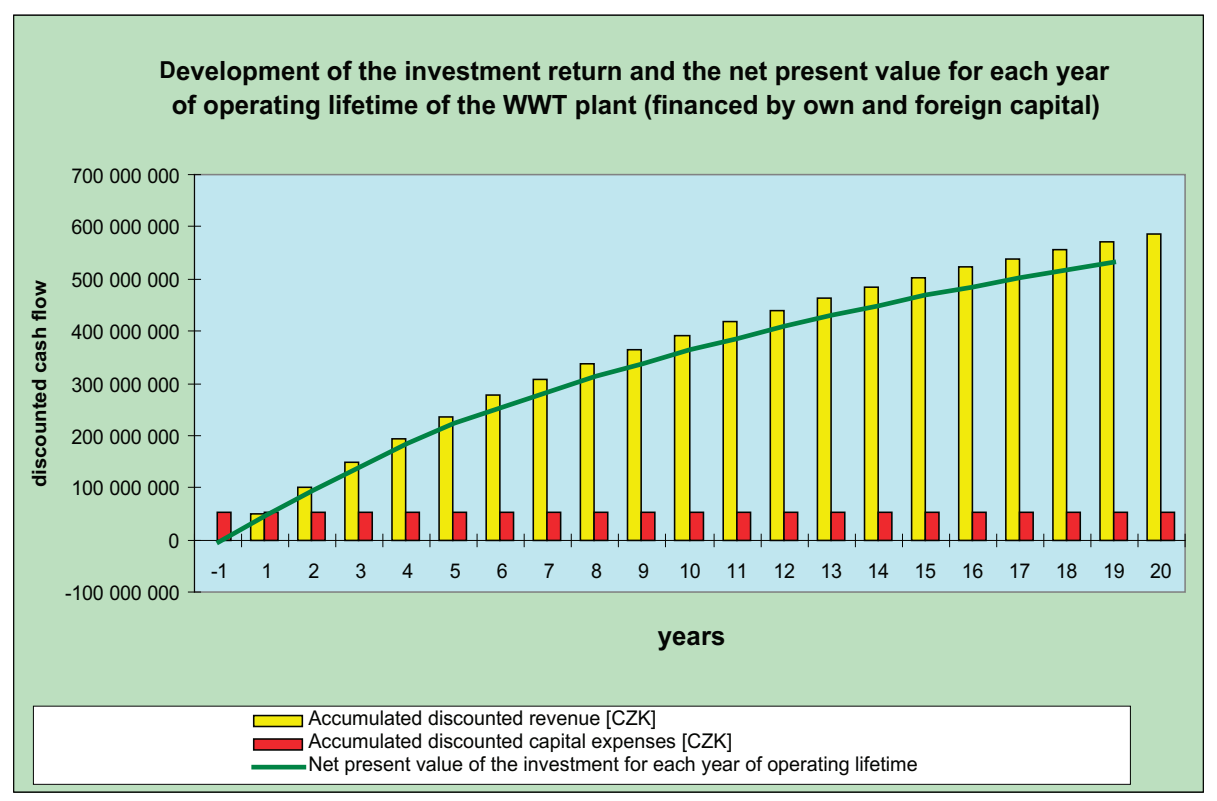

Figure 5: Development of the investment return and the net present value for each year of operating lifetime of the WWT plant using Anoxkaldnes ${ }^{\mathrm{TM}}$ (financed by own and foreign capital). Source: own.

The Net Present Value for the investment on the technology Anoxkaldnes ${ }^{\mathrm{TM}}$ taking into account own and foreign capital amounts 532574 240,- CZK. The Net Present Value after 15 years financed the same way amounts 449210616 ,- CZK. The internal rate of return is $65 \%$.

Figure 5 shows the relation between accumulated discounted revenue and accumulated discounted capital expenses including the net present value financed by own and foreign capital.

The Net Present Value for the investment on the technology for nano-fibrous carriers taking into account the optimization of the production amounts 7218 030,-CZK financed by own capital. The Net Present Value after 15 years financed the same way amounts $56443105,-\mathrm{CZK}$. The internal rate of return is $61 \%$.

Figure 6 shows the relation between accumulated discounted revenue and accumulated discounted capital expenses including the net present value financed by own and foreign capital.

The Net Present Value for the investment on the technology of nano-fibrous carriers taking into account of own and foreign capital amounts 66414 471,- CZK. The Net Present Value after 15 years financed the same way amounts $55493583,-\mathrm{CZK}$. The internal rate of return is $64 \%$.

Figure 7 shows the relation between accumulated discounted revenue and accumulated discounted capital expenses including The Net Present Value financed by own and foreign capital for the nanofibrous carrier.

\subsection{Production model}

This model includes

- the estimation of the annual production of DPG

- coeficients that preconceive detereminate percentages of the reduction in production increments

- the modified increment of the annual production of DPG. 


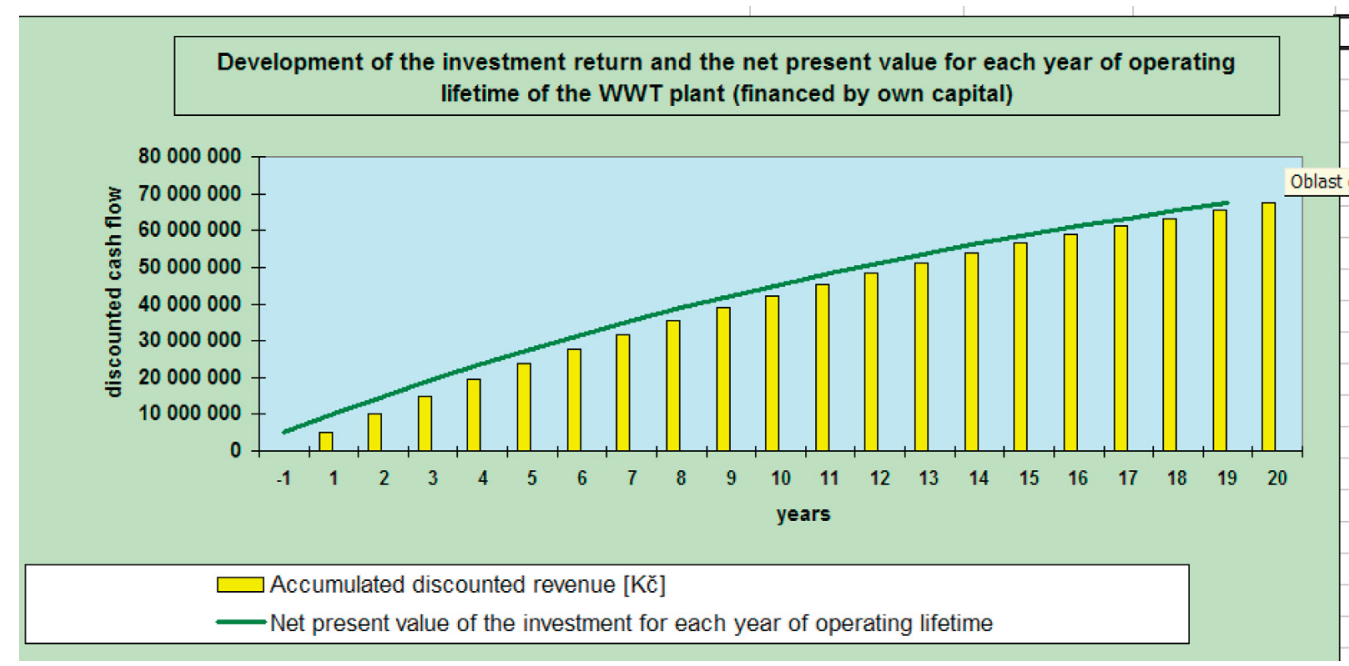

Figure 6: Development of the investment return and the net present value for each year of operating lifetime of the WWT plant using nano-fibrous carrier (financed by own capital). Source: own.

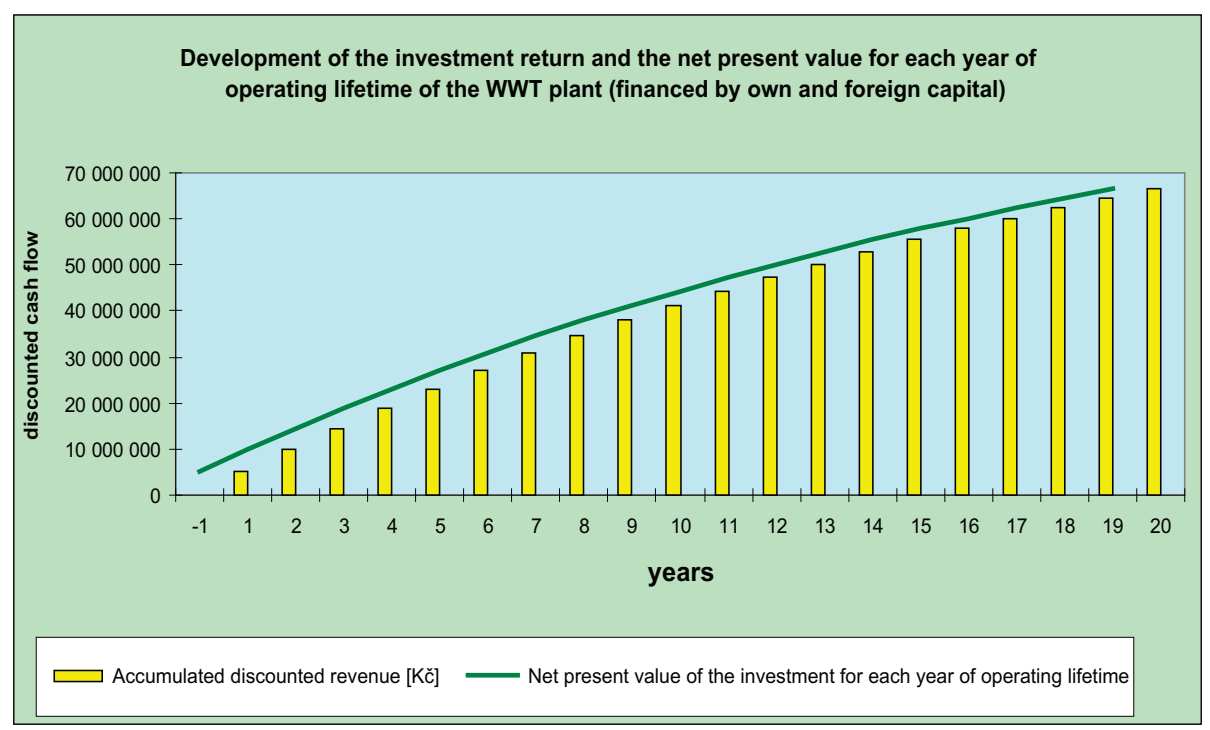

Figure 7: Development of the investment return and the net present value for each year of operating lifetime of the WWT plant using Nano-fibrous carrier (financed by own and external capital). Source: own.

In case of the utilization of Anoxkaldnes ${ }^{\mathrm{TM}}$ rings for the wastewater treatment technology, there were entered 1100 ton of the chemical material DPG, which equals the annual increment of this kind of filling. 160 ton per year were entered for the nano-fibrous carrier.

The next step for the model was to enter the coeficients that preconceive determinate percentages of the reduction in production increments. For WWT Plant using Anoxkaldnes ${ }^{\mathrm{TM}}$ the effect of shut 
downs in the production is represented by a coefficient of $9 \%$, and the coefficient of production limitation at 3\%. The same coefficients for the technology applying nano-fibrous carriers are $3 \%$ and $2 \%$ respectively.

The increment of the annual production of DPG is modified to 968 ton in case of losses. This increment is modified to 152 ton of the chemical material in the case of nano-fibrous carrier.

\subsection{Sensitivity analysis}

The sensitivity analysis was mainly developed in order to test variables such as price of applied carrier, time of renewal of the cleaning process for each carrier, price of production of the company, among others.

The sensitivity analysis for the effect of the prices and production of the chemical material DPG for the technology using Anoxkaldnes ${ }^{\mathrm{TM}}$ takes into account the effects of changes (deviations) from the prices of DPG (65 000,-CZK) and the modified annual production of 968 ton of DPG.

The analysis includes $10 \%, 20 \%$, and $30 \%$ deviations in both directions. With zero deviation of the production and price is the net present value of the investment 594241 189,-CZK.

The sensitivity analysis for the effect of the prices and production of the chemical material DPG for the technology using nano-fibrous carrier takes into account the effects of changes (deviations) from the prices of DPG (65 000,-CZK) and the modified annual production of 152 ton of DPG.

The analysis includes $10 \%, 20 \%$, and $30 \%$ deviations in both directions. With zero deviation of the production and price is the net present value of the investment 85809838 ,- CZK.

The sensitivity analysis for the effect of the prices of the chemical material DPG and the nanofibrous carrier shows the effects of changes (deviations) from the prices of DPG (65 000,-CZK) and the prices of the nano-fibrous carrier, respectively. The difference between the prices of both types of carriers is $334000,-\mathrm{CZK}$ above the Anoxkaldnes ${ }^{\mathrm{TM}}$ carrier. $^{-}$

The analysis includes 10\%, 20\%, and 30\% deviations in both directions. With zero deviation of the production and price is the net present value of the investment is 207399 577,- CZK.

The sensitivity analysis for the effect on the prices of the chemical material and the production of DPG due to shortcuts, which occurs statistically 1-2 times per year, shows the effects of changes (deviations) from the prices of DPG $(65000,-\mathrm{CZK})$ and the changes in the production of the chemical material DPG in case of shortcuts with the Anoxkaldnes ${ }^{\mathrm{TM}}$ carrier (968 $\mathrm{t}$ of DPG). The analysis includes $0-48 \%$ deviations, that means up to 6 shortcuts a year. In the case of a shortcut using Anoxkladnes carrier, there is a loss of $8 \%$ on the total annual production of DPG. With zero deviation of the production and price is the net present value of the investment 449975 726,- CZK.

The sensitivity analysis for the effect on the prices of the chemical material and the production of DPG due to shortcuts, which occurs statistically 1-2 times per year, shows the effects of changes (deviations) from the prices of DPG $(65000,-\mathrm{CZK})$ and the changes in the production of the chemical material DPG in case of shortcuts with the nano-fibrousiborus carrier (152 t of DPG) The analysis includes 0-30\% deviations, that means up to 6 shortcuts a year. In the case of a shortcut using nano-fibrous carrier, there is a loss of $4 \%$ on the total annual production of DPG. With zero deviation of the production and price is the net present value of the investment 85809838 ,- CZK.

\section{EVALUATION}

Each part of the economic model has been prepared in order to compare both carriers (Anoxkaldnes ${ }^{\mathrm{TM}}$ and nano-fibrous) within the process of wastewater treatment.

Table 2 shows the results of the cost analysis. Startup costs, reconstruction and optimization investments created an annual growth in the production of DPG of about $1100 \mathrm{t}$. In case the plant 
Table 2: Cost analysis summary.

\begin{tabular}{lcc}
\hline Costs & Anoxkaldnes $^{\mathrm{TM}}$ Biofilm & Nano-fibrous carrier \\
\hline Startup costs & $61979000,-$ CZC & \\
Reconstruction investments & $2248000,-$ CZC & \\
Optimization investments & $35500000,-$ CZC & \\
Non-capital costs for the technology & $3999000,-$ CZC & \\
Construction of the new deposit & & $2505000,-$ CZC \\
\hline
\end{tabular}

Source: own.

Table 3: Net present value model (own capital).

\begin{tabular}{lcc}
\hline Indicator & Anoxkaldnes $^{\mathrm{TM}}$ Biofilm & Nano-fibrous carrier \\
\hline NPV & $541372841,-$ CZC & $7218030,-$ CZC \\
NPV - recovery time 15 years- & $458009217,-$ CZC & $56443105,-$ CZC \\
IRR & $61 \%$ & $61 \%$ \\
\hline
\end{tabular}

Source: own.

Table 4. Net present value model (own + foreign capital).

\begin{tabular}{lcc}
\hline Indicator & Anoxkaldnes ${ }^{\mathrm{TM}}$ Biofilm & Nano-fibrous carrier \\
\hline NPV & $541372841,-$ CZC & $66414471,-$ CZC \\
NPV - 15 years- & $449210616,-$ CZC & $55493583,-$ CZC \\
IRR & $65 \%$ & $64 \%$ \\
\hline
\end{tabular}

Source: own.

operator decides to use nano-fibrous carriers, it will be necessary to invest on new fulfillment at the amount of 2505000, CZK. If the other parameters remain the same, it might be the only extra expenditure to be done.

The results and characteristics for financing the project for the wastewater treatment technology using nano-fibrous carrier, present positive values taking into account own and foreign capital. This makes the project very interesting for the investors. Tables 3 and 4 show the data.

The results of the economic model for this specific case show that the use of fiber carrier corresponds to a sustainable growth of the company and the local economy.

\section{CONCLUSIONS}

After completing this analysis, the authors went to the conclusion that the application of nano-carriers in the WWT technology has more economic advantages compared with the technology of Anoxkaldnes $^{\mathrm{TM}}$ carriers. These benefits are translated in high efficiency in disposal of contamination, quickly renewable cleaning process especially in case of accidents - shorter shut-down and smaller economic waste, better stability of cleaning process and less ecological burdens. 
The presented model describes the valuation of WWT technology under conditions of the Czech Republic. However, it can be adapted to other industrial branches where this form of biological wastewater treatment can be applied.

We also suggest applying more methods for the valuation of technologies in order to enhance the results of this work (e.g. decision trees, risk analysis, Monte Carlo Method, etc).

Besides the economic analysis it is important to follow the new developments on the technologies for carriers in wastewater treatment facilities.

\section{ACKNOWLEDGEMENTS}

This article was created under the state subsidy of the Czech Republic within the research and development project "Advanced Remediation Technologies and Processes Center"1M0554 - Programme of Research Centers supported by Ministry of Education.

\section{REFERENCES}

[1] Boer, F.P., Oceňování technologií, 1. vyd. Brno: Zooner Press, s.r.o. ISBN 978-80-86815-664, 2007.

[2] Mařík, M. \& Maříková, P., Moderní metody hodnocení výkonnosti a oceňování podniku, Praha: Ekopress, 2001, 70 p. ISBN 80-86119-36-X.

[3] Arnold, G., Corporate Financial Management, 3rd. ed. UK: Pearson Education Limited. 1200 s. ISBN 0-273-68726-3, 2005.

[4] Aguilar, C.S., Dubová, M. \& Mucsková, E., The valuation and financial management of (nano-) technology in relation to sustainable growth. Waste Management and Environment V. WIT Press. Southampton. 13 p. ISBN 978-1-84564-460-4, 2010.

[5] Internal materials of Company A.

[6] Homepage of the technology Anoxkaldnes ${ }^{\mathrm{TM}}$, http://www.anoxkaldnes.com/Eng/c1prodc1/ mbbr.htm,http://www.veoliawaterst.com/mbbr/cz/application s.htm

[7] Křiklavová, L. Technologický návrh biofilmového reaktoru s nanovlákenným nosičem pro čištění prümyslových odpadních vod-Diploma work, TUL, Fakulta mechatroniky, informatiky a mezioborových studií, 2009.

[8] Galerie materiáli̊. TUL, Fakulta textilní, Katedra netkaných textilií. Available from www: http://www.ft.tul.cz/depart/knt/nove/dokumenty/katedra/download/materialy_knt.pdf

[9] Brealey, R.A., Myers, S.C., Principles of Corporate Finance, New York: McGraw-Hill Companies, Inc. ISBN 0-07-114053-0, 1996.

[10] Král, B., A kol. Manažerské účetnictví, Praha: Management Press. ISBN 80-7261-141-0, 2006. 